\title{
Effect of Emotional Intelligence, Commitment, and Motivation Towards Lecturer Performance
}

\author{
Mukti Ali, Badri Munir Sukoco, Falih Suaedi \\ Departement of Management, Universitas Maarif Hasyim Latif, Sidoarjo \\ Postgraduate Program, Universitas Airlangga, Surabaya \\ Email : mukti_ali@dosen.umaha.ac.id
}

\begin{tabular}{|c||c||c||}
\hline Accepted : & Reviewed : & Published : \\
December, 112017 & January, 17 2018 & March, 30 2018 \\
\hline
\end{tabular}

\begin{abstract}
Purpose: Make a document key performance indicator associated with emotional intelligence, commitment, and motivation on the performance lecturer at the Universitas Maarif Hasyim Latif Sidoarjo.

Design/methodology/approach: The research uses quantitative methods to the associative and using regression analysis techniques and equational structure modeling for determining hypothesis.

Findings: The research was based on the findings of non-optimal lecturers performance in carrying out the task, they allegedly a violation of labor discipline, still high levels of absenteeism and tardiness in teaching.

Research limitations/implications: Predicting the magnitude of the variation, form relationships and determine the direction and magnitude of effect between the independent variables with the dependent variable.

Practical implications: Can document the whole process of planning and strategic steps in efforts to implement the increase in faculty performance through increased emotional intelligence, commitment, and motivation on the performance of a lecturer at the Universitas Maarif Hasyim Latif Sidoarjo.

Originality/value: An input for policy making in the improvement and development of the organization and management of universities, in particular, relating to the development Lecturer performance through the development of emotional intelligence, commitment, and motivation more.
\end{abstract}

Paper type: Research paper.

Keyword: Lecturer performance, emotional intelligence, commitment, motivation, human resources management.

\section{INTRODUCTION}

On higher education in Indonesia is often the criticism leveled out at the management and development of lecturers, it is because the efforts of the management and development section are often considered less relevant lecturer at the college of strategies to survive and win the competition. Factors that have an important role in contributing to the achievement of the vision, mission, and goals in a College of the Lecturers, as "Lecturers are human resources in direct contact with the parties concerned with a place or institution where he worked (Danim, 2002; Surya, 2011)".

Lecturers have an important meaning in the operations of a university. Lecturers have the functions and duties as an image builder (builder of the image) and as a bridge between the university and the public (students, employees, parents, professionals, etc.). In addition to the duties and functions of the principal lecturers are also required to be more proactive and responsive responding to and rectifying problems and

Effect of Emotional Intelligence, Commitment, and Motivation Towards Lecturer Performance

Mukti Ali, Badri Munir Sukoco, Falih Suaedi 
current issues emerging in the society which is in contact with the Higher Education policy implementation, so there is no distortion of information and communication in society. It was intended that the public can understand correctly and accurately to the policies and laws that produced the College. Lecturers performance and the result is determined by the lecturer of psychological factors of emotional intelligence. Differences in individual emotional intelligence have the potential to contribute to a better understanding of the implications of effective policy changes which take place in an organization (Trihandini, 2005; Fitriastuti, 2013; Rahmasari, 2016). Individuals with low emotional control would react negatively toward the proposed changes. In contrast, individuals with the ability to use emotions appropriately, optimistic and often also take the initiative, in general, decided to reframe their perceptions of the program of change recently introduced and looked at it as an exciting challenge (Colquitt et al., 2011).

People with positive emotional intelligence tend to be characterized by calm, excited, and safe (Gibson et al., 1991). While those who have negative emotional intelligence tend to be anxious, depressed, and insecure. Teacher to be able to carry out the teaching and learning activities with well needed positive emotional intelligence (Agustian, 2001; Danim, 2002). Conversely, if a teacher has a low emotional intelligence (negative) it is certain learning activities carried out will be less favorable. Lecturers are part of a system of school organization has a strategic role in achieving the goals of education. Therefore, committed lecturers at educational organizations is an important variable that needs attention to be studied. Commitment to this organization can be seen from one's ability to adapt to their environment, their high confidence level of education where duty, participation in decision-making, as well as loyalty and discipline.

The commitment of a person is an important factor, as it determines the quality of the relationship between an individual and as a member of the organization to organization. Organizational commitment is the attitude of someone in the organization who associate themselves with the organization's identity. Commitment is the power of the individual in identifying with the organization and its involvement in organizational tasks. Factors that are characteristic of commitment to the organization that is to believe and accept the values of the existing organization, the desire to strive on behalf of the organization, and the desire to remain a member of the organization. Three elements make up the organizational commitment of employees are satisfaction, identification, and involvement (Gerungan, 2004; Sarwono and Meinarno, 2009). When employees are satisfied in performing their duties and can adapt to the organization and feel involved in the activities of the organization, especially in decision-making, then the employee will have a high commitment to the organization (Gerungan, 2004).

Also, external factors also influence a lecturer in generating performance. The external factor is the motivation or support organization. Support organizations in education services, as well as other services in the field of employee performance improvement, is determined by the atmosphere in the organization created by the relationship or communication prevailing environment of the organization.

Based on Social Cognitive Theory, the writer tried to examine Effect of Emotional Intelligence, commitment, and motivation on Lecturer Performance Universitas Maarif Hasyim Latif. Emotional Intelligence as a lecturer of social-cognitive factors that build Self Efficacy where the social cognitive theory, self-efficacy has a great influence on the success of the learning process. Self-efficacy is an important influence on people's motivation because it involves a person's beliefs about things that are going to do. Which can affect self-efficacy among others mastery experience, physiological and emotional arousal, vicarious experience, as well as social persuasion?. In the process of learning, self-efficacy is needed both within the student as well as his teacher. Which in turn will bring up the name of Self-Regulated Learning, the process of activating and sustaining thoughts, behaviors, and emotions to achieve the goal?. The self-regulated learner has academic learning skills and self-control which makes learning easier.

\section{METHODOLOGY}

This study was conducted to elucidate the relationship between two variables, independent variables which include emotional intelligence lecturers $\left(\mathrm{X}_{1}\right)$, the commitment of lecturers $\left(\mathrm{X}_{2}\right)$, and motivation of lecturers $\left(\mathrm{X}_{3}\right)$ with the dependent variable is the performance $(\mathrm{Y})$. Then this type of research is quantitative with the type associative because researchers want to determine whether there is influence between variables by testing the hypothesis that has been formulated. To predict the magnitude of the variation, form

Effect of Emotional Intelligence, Commitment, and Motivation Towards Lecturer Performance Mukti Ali, Badri Munir Sukoco, Falih Suaedi 
relationships and determine the direction and magnitude of effect between the independent variables with the dependent variable using regression analysis techniques (Bungin and Sos, 2005). This research was conducted at Universitas Maarif Hasyim Latif Sidoarjo. The main reason is the choice of location for the location of the majority of lecturers between each other have different, emotional intelligence, commitment, and motivation. The study population was all a lecturer at Universitas Maarif Hasyim Latif Maarif much as 116 people. Samples were selected by 54 respondents drawn using proportional random sampling technique (Burhan, 2005; Ghozali and Latan, 2015). And then the empirical path for performance study can show in figure 1.

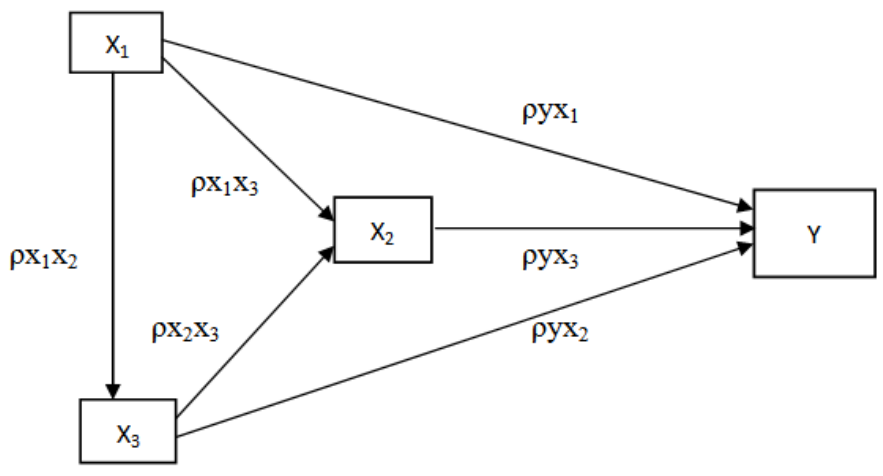

Figure 1 - Empirical path diagram of performances study

\section{RESULTS AND DISCUSSION}

\subsection{Analysis of Partial Least Square (PLS)}

PLS test is a method of analysis that is not based assumptions. Data should not normally distribute, with a nominal categorical scale, ordinal, interval until the ratio. PLS can be used to confirm the theory and explain whether there is any relationship between the latent variables. In processing the Partial Least Square (PLS) is carried out in two stages.

1. The first stage is to test the model measurement (measurement model) or the outer evaluation models.In this phase is essential to test the validity and reliability of the constructs or variables of the study. Readings construct validity and reliability is of value loading factor. Is said to be a valid and reliable indicator if it has a loading factor value greater than or equal to 0,5 .

2. The second stage is to test structural models or inner evaluation models. In this phase aims to determine whether there is influence between variables (Hypothesis Testing).

\subsubsection{Phase Measurement Model (Outer Testing Model)}

Here is a picture of the test results on the PLS phase model the measurement for variables emotional intelligence, commitment, and motivation related to the lecturer's performance at Universitas Maarif Hasyim Latif Sidoarjo. Tests are done together because the PLS procedure cannot be done if the test uses only one latent variable. The valid and reliable indicator is said to be a construct where the loading factor has a value greater than or equal to 0,5 . The first measurement is for factor loading of emotional intelligence have each item indicators, there are 16 items that valid and reliable indicator of where the value of the factor loading $>0.50$ and 11-item indicators are not valid and reliable where the factor loading scores are $<0.50$. So a valid and reliable indicator of some $59.3 \%$ were the invalid and reliable amount of $40.7 \%$. So that the value of factor loading indicator constructs qualifies $(>0.50)$ then all indicators constructs $<0.50$ should be dropped and the next model in RUN back. (Ghozali, 2014). There are several possible non-fulfillment of validity for some items instruments emotional intelligence because:

1. The hesitations faculty to assess/evaluate yourself. 
2. Lecturer in giving less attention to their answers unfavorable instruments.

3. The term used in the questionnaire are multiple interpretations.

The second measurement is for factor loading of commitment have each item indicators there are 14 items that valid and reliable indicator of where the value of the loading factor $>0.50$ and 4 item indicators are not valid and reliable where the value factor loading $<0.50$. So a valid and reliable indicator of some $82.4 \%$ were the invalid and reliable amount of $17.6 \%$. So that the value of factor loading indicator constructs qualifies $(>0.50)$ then all indicators constructs $<0.50$ should be dropped and the next model in RUN back. (Ghozali, 2014). There are several possible non-fulfillment of validity for some items instrument commitment because the similarity between the questions of one another to confuse the respondent and phrases used allows the respondent to give biased answers.

The third measurement is for factor loading of each item indicators there are 21 items that valid and reliable indicator of where the value of the loading factor $>0.50$ and 9 item indicators are not valid and reliable where the loading factor values $<0.50$. So a valid and reliable indicator of some $70 \%$ was an invalid and reliable number of $30 \%$. So that the value of factor loading indicator constructs qualifies $(>0.50)$ then all indicators constructs $<0.50$ should be dropped and the next model in RUN back. There are several possible non-fulfillment of validity for some motivation indicator instrument item because:

1. The term used in the questionnaire are multiple interpretations.

2. Instruments The question does not support the indicator variables.

The fourth measurement is for factor loading of each item performance indicators overall (100\%) are valid and reliable. For all items Loading Indicator Value Factor $<0.50$ (Invalid) and then we drop all our models Run back so that all items are indicators that there are only having Loading factor $>0.50$. Once an item is declared invalid indicator (Value Loading Factor $<0.50$ ) we drop all, then when we construct using Application Program Smart PLS 3.0 as shown in figure 2:

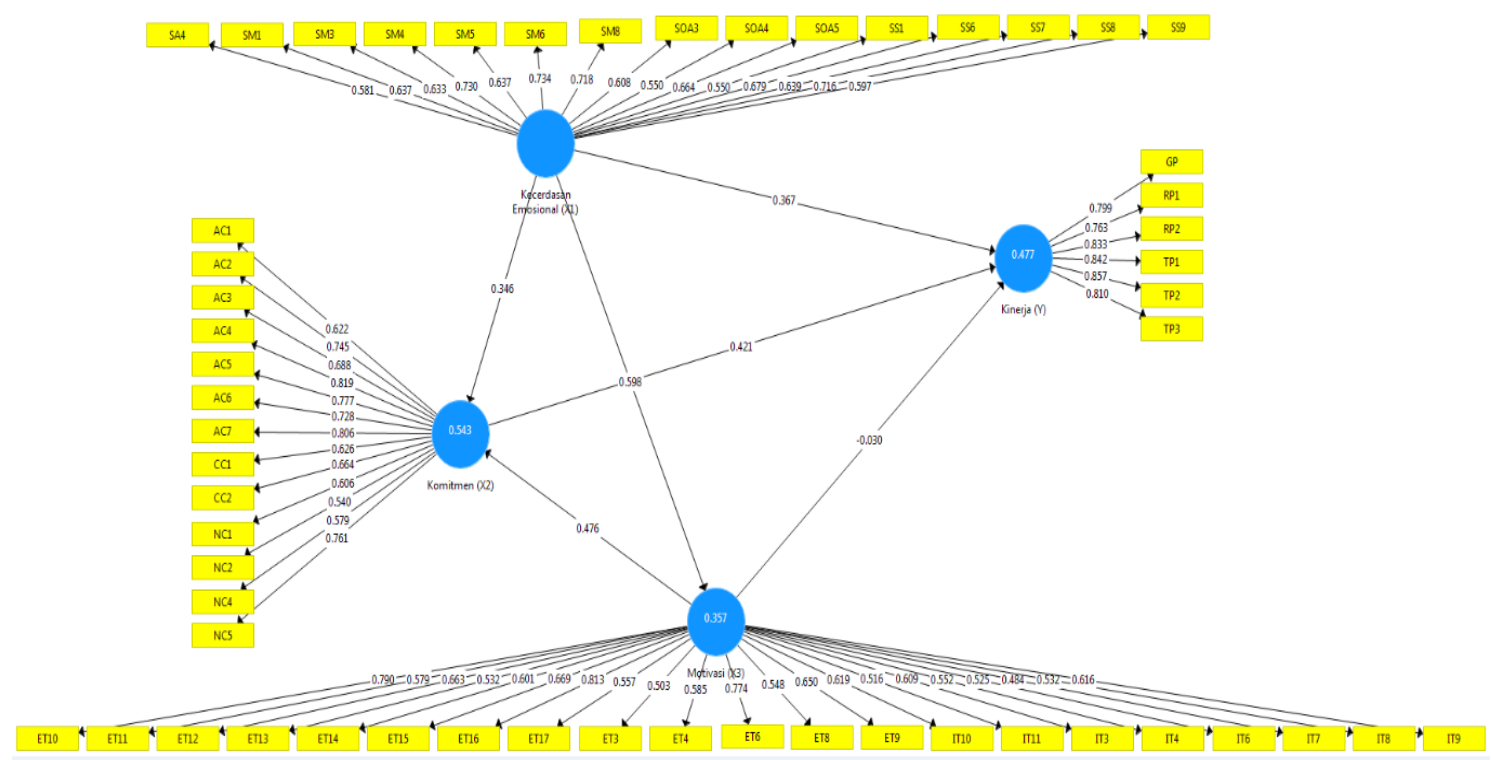

Figure 2 - Results of Measurement Model (Outer Weight) with Smart PLS 3.0

\subsubsection{Phase Structural Model Testing (Inner Testing Model)}

Phase model Structural This aims to determine whether there is influence between variables. Testing performed using the t-test. Variable is said to affect when $t$ (T-Statistics) $>t$ table. Where $t$ is the table in this study was ( $\mathrm{t} \alpha / 2, \mathrm{n}-1$ ), on the significance (two-tailed) level of $0.05=1.671$. Likewise, if there is a relationship between variables is negative then the decision is if $t$ count smaller than $t$ table. Based on the measurement of the relationship between variables with indicator item can be interpreted coefficient estimation: 
1. The number of coefficient estimates of each variable on all the indicators Item>0.50 it can be concluded that the relationship between the variables with each instrument is a significant indicator.

2. The amount of the $\mathrm{t}$ (T Statistics) each Item Indicators> 1.671 so that it can be said that each item is a valid indicator as a measure of the construct variables.

According to results of variable estimated coefficient intergovernmental relations, the estimated coefficients can be interpreted value:

1. Amount of coefficient estimation of Emotional Intelligence (X1) on the performance of Lecturer $(\mathrm{Y})$ is 0,367 . The coefficient is positive, which means that if a lecturer was further enhanced emotional intelligence, the higher the performance of the lecturers. And conversely the lower the emotional intelligence lecturer than the lower the coefficient of performance of lecturers with 0,367 .

2. Coefficient estimation of Emotional Intelligence (X1) of the Commitments Lecturer (X2) is 0.346. The coefficient is positive, which means that if a lecturer was further enhanced emotional intelligence, the higher the faculty's commitment to the organization. And conversely, the lower the emotional intelligence, the lower lecturer performance is also a commitment to the organization with a coefficient of 0.346 .

3. Amount of coefficient estimation of Emotional Intelligence (X1) of the Motivation Lecturer (X3) is 0.598 . The coefficient is positive, which means that if a lecturer was further enhanced emotional intelligence the higher work motivation lecturers. And conversely, the lower the emotional intelligence lecturer will get the low motivation of the faculty work with a coefficient of 0.598 .

4. Amount of coefficient estimates of Commitment (X2) on the Performance of Lecturer (Y) is 0.421. The coefficient is positive, which means that if the commitment was further enhanced faculty, the higher the performance of the lecturers. And conversely, the lower the commitment of lecturers will get the low performance of lecturers with a coefficient 0.421 .

5. Amount of coefficient estimates of motivation(X3)on the Performance of Lecturer (Y) is 0,030. The coefficient is negative, which means when the lecturer has further enhanced motivation to work, the lower the performance of the lecturers. And conversely the lower the motivation to work, the higher the lecturer of the faculty performance coefficient 0,030 .

6. Amount of coefficient estimates of Motivation (X3) of the Commitments (X2) is 0.476. The coefficient is positive, which means that if a lecturer was further enhanced motivation to work, the higher the faculty's commitment to the organization. And conversely, the lower the lecturers work motivation will get a low commitment to the organization's lecturers with a coefficient of 0.476 .

7. From the point 5 and 6 above can be noted that there is no effect on the Performance Work Motivation Lecturer directly (no significant correlation), but the influence of Work Motivation Performance Lecturer to be strong when it first passed commitment (there is a strong and significant relationship through commitment).

Results structural Model (Inner Testing Model) which is also called analysis bootstrapping model if we are constructing the Application Program Smart PLS 3.0 as shown in figure 3. 


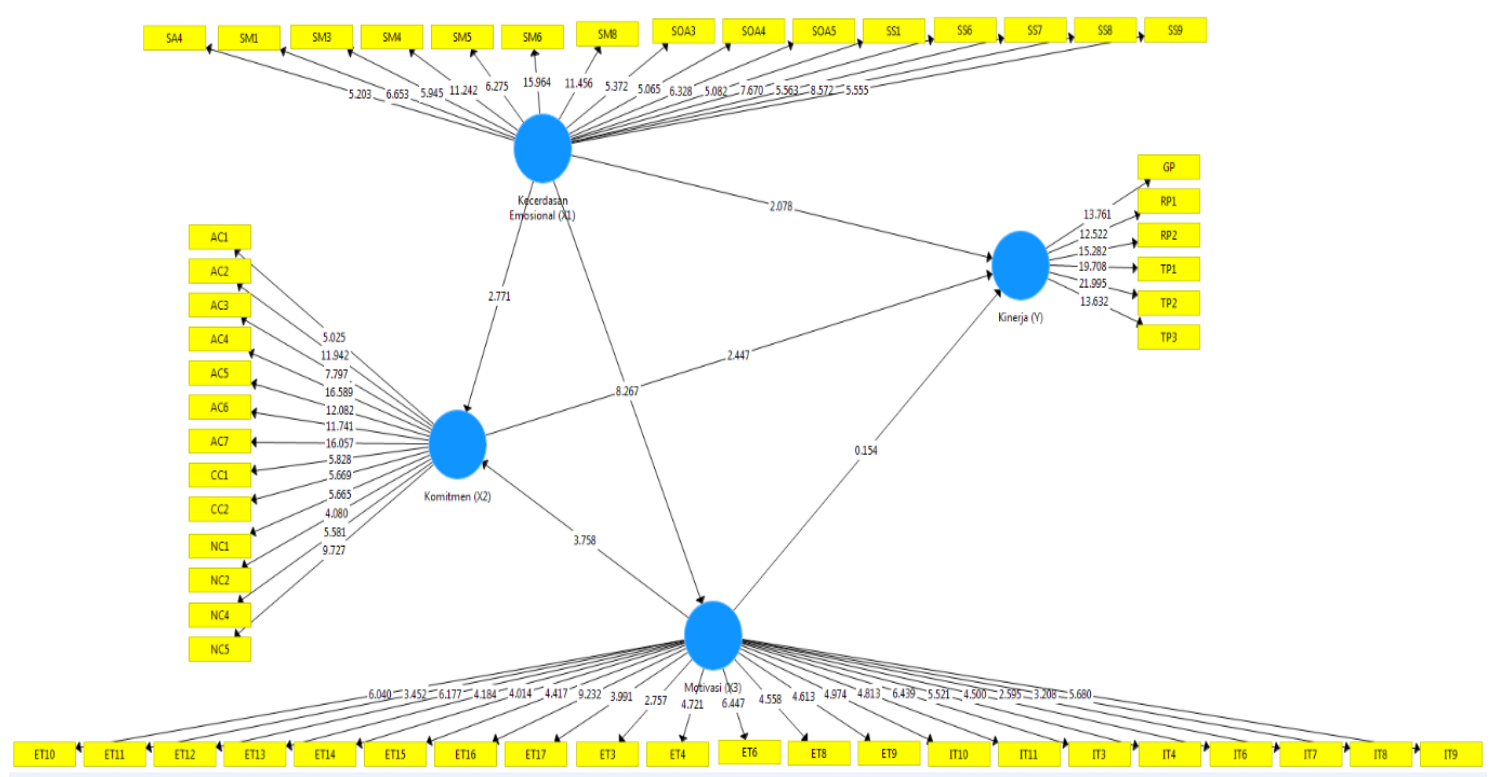

\subsection{Hypothesis testing}

Figure 3 - Test results $t$ stage structural model

Hypothesis Testing using PLS analysis through bootstrapping the model is to look at Coefficientnya Path. If the Q Statistic $(\mathrm{t})$ is greater than $\mathrm{t}$ table (T Table for 54 Respondents to the 0.05 level of significance $=1.671)$, the Ha Ho accepted and rejected. Conversely, when Q Statistic $(\mathrm{t})$ is less than $\mathrm{t}$ table (T Table for 54 Respondents $=1.671)$, then Ha is rejected, and Ho received, where:

$\mathrm{Ha}=$ There is a relationship between variable $\mathrm{X}$ and variable $\mathrm{Y}$

$\mathrm{Ho}=$ There is no relationship between the variables $\mathrm{X}$ and variable $\mathrm{Y}$

Table 1 - The results of the $t$ Interpersonal Variables (Path Coefficient)

\begin{tabular}{|l|l|l|l|}
\hline \multicolumn{1}{|c|}{ Relationship between Variable } & \multicolumn{1}{|c|}{$\begin{array}{c}\text { Original } \\
\text { Sample } \\
\text { Estimate }\end{array}$} & $\mathrm{t}$ & \multicolumn{1}{|c|}{ Description } \\
\hline Emotional Intelligence (X1) -> Performance (Y) & 0,367 & 2,078 & H1 accepted \\
\hline Emotional Intelligence (X1) -> Commitment (X2) & 0.346 & 2.771 & H2 received \\
\hline Emotional Intelligence (X1) -> Motivation (X3) & 0.598 & 8.267 & H3 received \\
\hline Commitments (X2) -> performance (Y) & 0.421 & 2.447 & H4 acceptable \\
\hline motivation (X3) -> performance (Y) & -0.030 & 0.154 & H5 rejected \\
\hline motivation (X3) -> commitment (X2) & 0.476 & 3.758 & H6 accepted \\
\hline
\end{tabular}

From the results of Path Coefficient above can be seen that:

1) Hypothesis 1: Q Statistic ( $\mathrm{t})$ variable EQ $\left(\mathrm{X}_{1}\right)$ to variable Performance $(\mathrm{Y})$ is equal to 2,078>t table (1.671), which means that the variable EQ $\left(\mathrm{X}_{1}\right)$ affect the performance variable $(\mathrm{Y})$ is true.

2) Hypothesis 2: $Q$ Statistic (t) variable $E Q\left(X_{1}\right)$ to variable Commitment $\left(X_{2}\right)$ is equal to 2,771>t table (1.671), which means that the variable EQ $\left(\mathrm{X}_{1}\right)$ affect the Variable Commitment $\left(\mathrm{X}_{2}\right)$ is correct.

3) Hypothesis 3: Q Statistic (t) variable EQ $\left(\mathrm{X}_{1}\right)$ to variable motivation $\left(\mathrm{X}_{3}\right)$ is approximately 8.267> $\mathrm{t}$ table (1.671), which means that the variable EQ $\left(X_{1}\right)$ effect on variable Motivation $\left(X_{3}\right)$ is correct. 
4) Hypothesis 4: $Q$ Statistic (t) Variable Commitment $\left(X_{2}\right)$ to variable Performance $(Y)$ is equal to 2,447> t table (1.671), which means that the variable Commitment $\left(\mathrm{X}_{2}\right)$ effect on the Variable Performance $(\mathrm{Y})$ is right.

5) Hypothesis 5: Q Statistic (t) Variable Motivation $\left(\mathrm{X}_{3}\right)$ to variable Performance $(\mathrm{Y})$ is equal to $0,154<t$ table (1.671), which means that the variable Motivation $\left(\mathrm{X}_{3}\right)$ does not affect the Variable Performance $(\mathrm{Y})$ directly.

6) Hypothesis 6: Q Statistic ( $t$ ) Variable Motivation $\left(\mathrm{X}_{3}\right)$ to variable Commitment $\left(\mathrm{X}_{2}\right)$ is equal to 3,758> t table (1.671). Which means that the variable motivation $\left(\mathrm{X}_{3}\right)$ affects Variable Commitment $\left(\mathrm{X}_{2}\right)$. Which also means that the motivation variable $\left(\mathrm{X}_{3}\right)$ can affect the performance variable $(\mathrm{Y})$ when preceded by Commitment.

\section{CONCLUSION}

Research shows that emotional intelligence factors greatly affect Lecturer performance. Efficacy of self-built by emotional intelligence is important personal variables which when combined with specific objectives and understanding will be the determinant of behavior in the future. Each has self-efficacy are different in different situations, depending on the capabilities demanded by different situations, the presence of other people as well as the emotional and physiological condition of the individual. Further shows the commitment factor affects the lecturer performance. Given that the instruments tend to be more variable Motivation leads to organizational factors, but less leads to personal factors (beliefs, expectations, attitudes, and knowledge) of the lecturers. Later that commitment will moderate the motivation for the performance, in other words, the commitment of an intervening variable for motivation. So motivation is built will be a positive and significant effect on performance if the development of commitment in it accompanies the motivation. This study showed that motivation (organizational factors) does not affect the performance of lecturers directly. Performance lecturer at Universitas Maarif Hasyim Latif does not depend on the motivation given by organizational factor directly. Based Social-Cognitive Theory of Bandura explained that lecturers who have high emotional intelligence would have self-efficacy a high as well, in other words, the motivation would be born in the person of the lecturers. So encouragement from the outside (factors of the organizational) provided will not mean much for the lecturers for can not touch personal factors (beliefs, expectations, attitudes, and knowledge) of the lecturers. If we have a sense of efficacy a high in a particular field, we will set higher goals, not too afraid to fail, and discover a new strategy if the old strategy failed. So the motivation born of Self Efficacy is more dominant in establishing the performance of the motivation created from organizational factors.

\section{REFERENCES}

Agustian, A. G. (2001) Rahasia sukses membangun kecerdasan emosi dan spiritual, ESQ (Emotional Spiritual Quotient): berdasarkan 6 rukun Iman dan 5 rukun Islam. Arga Wijaya Persada.

Bungin, P. D. H. M. B. and Sos, S. (2005) Metodologi penelitian kuantitatif. Kencana.

Burhan, B. (2005) 'Metodologi Penelitian Kuantitatif: Komunikasi', Ekonomi, dan Kebijakan Publik Serta Ilmu-ilmu Sosial Lainnya, Jakarta, Kencana Prenada Media Group.

Colquitt, J. et al. (2011) Organizational behavior: Improving performance and commitment in the workplace. McGraw-Hill Irwin.

Danim, S. (2002) Inovasi pendidikan dalam upaya peningkatan profesionalisme tenaga kependidikan. Pustaka Setia. 
Fitriastuti, T. (2013) 'Pengaruh Kecerdasan Emosional, Komitmen Organisasional Dan Organizational Citizenship Behavior terhadap Kinerja Karyawan’, Jurnal Dinamika Manajemen, 4(2).

Gerungan, W. A. (2004) 'Psikologi sosial'. Bandung: Refika Aditama.

Ghozali, I. and Latan, H. (2015) 'Partial Least Squares, Konsep, Teknik Dan Aplikasi Menggunakan Program Smartpls 3.0 Untuk Penelitian Empiris', Semarang: Badan Penerbit UNDIP.

Gibson, J. L. et al. (1991) Organizations: Behavior, structure, processes. Irwin Homewood, IL.

Rahmasari, L. (2016) 'Pengaruh Kecerdasan Intelektual, Kecerdasan Emosi dan Kecerdasan Spiritual Terhadap Kinerja Karyawan’, Majalah Ilmiah Informatika, 3(1).

Sarwono, S. W. and Meinarno, E. A. (2009) 'Psikologi sosial', Jakarta: Salemba Humanika, 77.

Surya, D. E. (2011) 'Kompetensi Dosen Terhadap Standarisasi Layanan kepada Mahasiswa', Jurnal Majalah Ilmiah Unikom, 6(2), pp. 157-168.

Trihandini, R. A. F. M. (2005) 'Analisis Pengaruh Kecerdasan Intelektual, Kecerdasan Emosi, dan Kecerdasan Spiritual Terhadap Kinerja Karyawan (Studi Kasus pada Hotel Horison Semarang)'. Program Pascasarjana Universitas Diponegoro. 